\title{
Detection of feral transgenic oilseed rape with multiple-herbicide resistance in Japan
}

\author{
Mitsuko AONO $^{1 *}$, Seiji WAKIYAMA ${ }^{2}$, Masato NAGATSU ${ }^{2}$, Nobuyoshi NAKAJIMA ${ }^{1}$, Masanori TAMAOKI ${ }^{1}$, \\ Akihiro KUBO ${ }^{1}$ and Hikaru SAJI \\ ${ }^{1}$ Environmental Biology Division, National Institute for Environmental Studies, 16-2 Onogawa, Tsukuba, 305-8506, Japan \\ ${ }^{2}$ Japan Wildlife Research Center, 3-10-10 Shitaya, Taito-Ku, Tokyo, 110-8676, Japan
}

Repeated monitoring for escaped transgenic crop plants is sometimes necessary, especially in cases when the crop has not been approved for release into the environment. Transgenic oilseed rape (Brassica napus) was detected along roadsides in central Japan in a previous study. The goal of the current study was to monitor the distribution of transgenic oilseed rape and occurrence of hybridization of transgenic $B$. napus with feral populations of its closely related species (B. rapa and $B$. juncea) in the west of Japan in 2005. The progenies of 50 B. napus, 82 B. rapa and 283 B. juncea maternal plants from 95 sampling sites in seven port areas were screened for herbicide-resistance. Transgenic herbicide-resistant seeds were detected from $12 B$. napus maternal plants growing at seven sampling sites in two port areas. A portion of the progeny from two transgenic $B$. napus plants had both glyphosate-resistance and glufosinate-resistance transgenes. Therefore, two types of transgenic $B$. napus plants are likely to have outcrossed with each other, since the double-herbicide-resistant transgenic strain of oilseed rape has not been developed intentionally for commercial purposes. As found in the previous study, no transgenic seeds were detected from $B$. rapa or $B$. juncea, and more extensive sampling is needed to determine whether introgression into these wild species has occurred.

Keywords: Brassica / establishment / glufosinate / glyphosate / herbicide / introgression / outcrossing / transgenic plant

\section{INTRODUCTION}

As the amount of transgenic crops that are cultivated, transported and used for food and feed had markedly increased in the last decade (ISAAA, 2006), accumulation of information about escaped transgenic crop plants is required for assessment and management of ecological risks posed by these transgenic plants (EFSA, 2004). Most of the commercially grown transgenic crop plants are not invasive or persistent, and introduced traits such as herbicide-, disease- or pest-resistance in these plants are thought to have little effect on their fitness in natural habitats, suggesting that they have extremely restricted potential for ecological effects (e.g., Crawley et al., 2001). Some crop plants, however, such as Brassica napus L., B. rapa L. and B. juncea (L.) Czern., are able to escape and survive as agricultural weeds in natural habitats (OECD, 1997). In Japan, these Brassica species have been imported since ancient times to be used mainly for food processing and some of them are feral at present: populations of these Brassica species are often found growing outside cultivated areas, $e . g$. along roadsides and riverbanks, as in other countries (OGTR, 2002; Saji et al., 2005), although the self-perpetuation of these populations has not yet been demonstrated in Japan.

Three types of herbicide-resistant transgenic oilseed rape (B. napus) have been approved to be imported into Japan: glyphosate-, glufosinate- and bromoxynil-resistant varieties, and only one has been approved for cultivation (glyphosate-resistant). Glyphosate resistance is conferred by a single genetic construct containing two genes: one encoding a herbicide-insensitive 5-enolpyruvylshikimate-3- phosphate synthase from Agrobacterium sp. CP4 (CP4 EPSPS) (Barry et al., 1992; Padgette et al., 1995), the target enzyme for glyphosate (Comai et al., 1985), and the other encoding glyphosate oxidoreductase, an enzyme

\footnotetext{
* Corresponding author: maono@nies.go.jp
} 
that degrades glyphosate (Barry and Kishore, 1995). Glufosinate resistance is conferred by a single bar gene encoding phosphinothricin- $\mathrm{N}$-acetyltransferase (PAT), an enzyme that inactivates glufosinate (Thompson et al., 1987). Additionally, the male-sterility trait was introduced into the glufosinate-resistant variety by inserting the barnase gene, isolated from Bacillus amyloliquefaciens (Mariani et al., 1990). The barnase gene encodes a ribonuclease that is expressed only in the tapetum cells of the pollen sac during anther development under the control of a tapetum-specific promoter. The ribonuclease affects RNA production, disrupting normal cell functioning and arresting early anther development, thus leading to male sterility. Male sterility of the glufosinate-resistant variety can be restored by the barstar gene, also isolated from Bacillus amyloliquefaciens (Mariani et al., 1992). The barstar gene encodes a ribonuclease inhibitor that specifically inhibits barnase ribonuclease. Thus, a barnase/barstar hybrid line that can develop normal anthers and has restored fertility can be produced by a pollination control system: crossing two lines of the glufosinateresistant variety that also bear either barnase or barstar. The glufosinate-resistant varieties with barstar and/or barnase in addition to bar have been approved to be imported into Japan. Bromoxynil resistance is conferred by a single bxn gene isolated from the bacterium Klebsiella pneumoniae (subsp. ozaenae), which encodes a nitrilase enzyme that hydrolyzes oxynil herbicides, ioxynil and bromoxynil, to non-phytotoxic compounds (Stalker et al., 1988).

Little oilseed rape is cultivated in Japan at present, so most of the oilseed rape consumed in Japan is imported. Although the glyphosate-resistant B. napus has been approved for cultivation, importation, and distribution as food, no transgenic B. napus has been commercially cultivated in this country. According to the trade statistics of the Japanese Ministry of Finance, of 2.3 Mt of oilseed rape imported into Japan in 2004, approximately $73 \%$ was imported from Canada, $27 \%$ was imported from Australia, and less than $0.002 \%$ each were from United States and Poland. Roughly $77 \%$ of Canada's oilseed rape was derived from transgenic varieties in 2004 (USDA, 2005b). Of the total B. napus grown in Canada in 2001, $47 \%$ was glyphosate-resistant, $13 \%$ was glufosinate-resistant and less than $1 \%$ was bromoxynil-resistant (Warwick et al., 2004). The former two herbicide-resistant varieties are grown not only in Canada but also in United States (ISAAA, 2006), however, very little oilseed rape was imported into Japan from United States as described above. With regard to Australia, Biotechnology Australia (http://www.biotechnology.gov.au/), an Australian
Government Initiative, and USDA (2005a) stated that transgenic oilseed rape has been approved for commercial release in 2003 in Australia, but was not widely grown there. Accordingly, herbicide-resistant transgenic oilseed rape distributed in Japan is thought to be chiefly glyphosate-resistant and glufosinate-resistant varieties imported from Canada. In this study, we focused on these two varieties.

Feral B. napus plants with glyphosate- or glufosinateresistance transgenes have been found since 2003 in several areas where major ports exist in Japan (Saji et al., 2005). It is thought to be inevitable that transgenic oilseed rape plants with herbicide resistance, sometimes with multiple resistance as a result of spontaneous intraspecific crossing, will be found growing at locations within and outside cultivated areas in countries such as Canada where herbicide-resistant transgenic oilseed rape are widely cultivated (Beckie et al., 2003; Friesen et al., 2003; Hall et al., 2000). On the other hand, since transgenic oilseed rape plants have not been commercially cultivated in Japan, their feral presence was probably a result of spillage during transportation (Saji et al., 2005). Outcrossing rates between $12 \%$ and $47 \%$ can occur between adjacent plants in $B$. napus, while the rates of crosses between $B$. napus and $B$. rapa have been reported to be from less than $1 \%$ to over $90 \%$, depending on the experimental design, and those between $B$. napus and B. juncea have been reported to be about 3\% (Becker et al. 1992; Bing et al., 1996; Jørgensen et al., 1996; reviewed in OGTR, 2002). These observations indicate that intraspecific outcrossing and hybridization between $B$. napus and two other Brassica species does occur under field conditions. Hybrids between $B$. napus and B. rapa and between B. napus and $B$. juncea were male-fertile and produced seeds although their fertility was lower than their parents (Bing et al., 1996), so the possibility of genetic introgression between B. napus and two other Brassica species exists. Therefore, it is necessary to monitor for the presence of transgenic oilseed rape plants and transgenic wild relatives to understand the extent of transgene introgression into feral and wild Brassica populations in Japan. Our previous investigation covered the central part of Japan, mainly the Kanto district (Saji et al., 2005). In the present study we investigated oilseed rape and closely related species growing at several port areas in western Japan, including roadsides and riverbanks behind the ports. We demonstrated the presence of oilseed rape plants with both glyphosate-resistance and glufosinate-resistance transgenes, suggesting the onset of intraspecific flow of the transgenes in the current habitats of feral oilseed rape plants. 


\section{RESULTS AND DISCUSSION}

\section{Detection of transgenic seeds in feral oilseed rape plants}

The seeds of three Brassica species, B. napus, B. rapa and $B$. juncea, were collected from 50, 82 and 283 maternal plants growing at 20, 17 and 58 sampling sites, respectively, in seven areas west of Tokyo where major ports are located (Fig. 1a and Tab. 1). Sampling sites in each area were classified into three types: ports, roadsides (sites along roads leading away from the ports) and riverbanks behind the ports (Tab. 1). Roadsides appear to have the majority of $B$. napus but very little $B$. rapa and $B$. juncea, while riverbanks seem to have the majority of B. rapa and B. juncea (Tab. 1).

The progeny of 415 maternal plants of three Brassica species growing at 95 sampling sites in seven port areas in the west of Japan were screened by herbicide treatment of a total of about 1800 B. napus, 1600 B. rapa and 6500 $B$. juncea seedlings grown from the collected seeds (Tab. 1), and also by immunochemical analyses of portions of the collected seeds. A total of 12 B. napus maternal plants growing at seven sampling sites in two port areas had herbicide-resistant progeny. All of the herbicideresistant seedlings had morphological characters of $B$. napus, such as bold white veins, whitish shiny leaf surface and leaf margin divided into two parts. Five plants growing at four sampling sites had glyphosate-resistant seeds, five plants growing at four sampling sites had glufosinateresistant seeds and two plants growing at one sampling site had both glyphosate-resistant and glufosinate-resistant seeds (Fig. 1a and Tab. 2). The proportion of sampling sites with herbicide-resistant seeds to the total number of sampling sites was 0.07 (seven positive sampling sites out of 95 sampling sites), while it was 0.15 (22 positive out of 143) in the central area of Japan in 2004 (Saji et al., 2005). As described in the introduction, nearly $100 \%$ of oilseed rape consumed in Japan is imported. In 2004, approximately $73 \%$ of the total oilseed rape imported into Japan was from Canada, and roughly $77 \%$ of total oilseed rape produced in Canada was transgenic herbicide-resistant varieties (USDA, 2005b). Thus, about half of the oilseed rape imported and distributed in Japan in 2004 is thought to have been transgenic herbicide-resistant. The proportion of transgenic herbicide-resistant B. napus maternal plants found in this investigation was $24 \%$ of total B. napus maternal plants, which is lower than this value, probably because not all of $B$. napus maternal plants were derived from recently imported seeds.

The existence of transgenes cp4 epsps for CP4 EPSPS, which confers resistance to glyphosate (Barry et al., 1992;
Padgette et al., 1995), and/or bar for PAT, which confers resistance to glufosinate (Thompson et al., 1987), in the seedlings that survived herbicide treatments was confirmed by PCR using specific primers (Tab. 3). PCR products of $320 \mathrm{bp}$ and/or $330 \mathrm{bp}$ were obtained using a part of a leaf of the glyphosate-resistant and/or the glufosinate-resistant seedlings, respectively (Fig. 2a and $2 \mathrm{~b})$. The nucleotide sequence of the PCR product obtained by using cp4 epsps primers was identical to a part of the DNA sequence for a cp4 epsps gene registered in INSD (the International Nucleotide Sequence Databases) as plural entries, for example, as accession no. I44001. Similarly, the sequence of the PCR product obtained by using bar primers was identical to a part of the sequence for a bar gene, registered in INSD as plural entries, for example, as accession no. X05822. Existence of the herbicide-resistance proteins in the collected seeds was also confirmed by the immunochemical method (Fig. 2c and $2 \mathrm{~d}$ ). All of the maternal plants shown in Table 2 were found to have the corresponding herbicide-resistance protein(s), as well as the transgene(s) for each herbicide resistance, in the leaves of their progeny seedlings (data not shown).

Transgenic seeds were detected in Yokkaichi and Hakata areas out of the seven port areas that we investigated (Fig. 1 and Tab. 2). Since these two areas include major ports of entry for oilseed rape imported mainly from Canada, the transgenes are likely to have been derived from imported seeds that were spilled during transportation. Four sampling sites on Yokkaichi roadsides where herbicide-resistant seeds were detected were distributed over ca. $40 \mathrm{~km}$ of route 23 , which is a transportation route from Yokkaichi port. Location 1-03 was ca. $5 \mathrm{~km}$ south of Yokkaichi port, sampling sites 105 and 1-06, which were ca. $300 \mathrm{~m}$ apart from each other, were ca. $15 \mathrm{~km}$ south-west of sampling site 1-03, and sampling site 1-07 was ca. $20 \mathrm{~km}$ south of the previous two adjacent sampling sites (Fig. 1b). In addition, sampling site 4-02 on a Yokkaichi riverbank was under a bridge over a river on route 23 , and was only ca. $300 \mathrm{~m}$ from sampling site 1-03 on the other side of the river (Fig. 1b). Locations 1-15 and 1-16 in the Hakata port, a few hundred meters from each other, were situated on a pier. These observations show that the oilseed rape plants with transgenic seeds were found exclusively along the arterial roads. Hence, it is strongly suggested that the existence of the feral transgenic oilseed rape plants was caused by the spillage of imported seeds, as Saji et al. (2005) also previously stated. Other sources of the transgenes are unlikely, since transgenic oilseed rape plants are not cultivated in Japanese fields. At sampling site 1-06, where 
M. Aono et al.

a

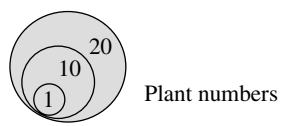

B. napus without herbicide resistant seeds

B. napus with glyphosate-resistant transgenic seeds

B. napus with glufosinate-resistant transgenic seeds

B. napus with glyphosate- and glufosinate-resistant transgenic seeds
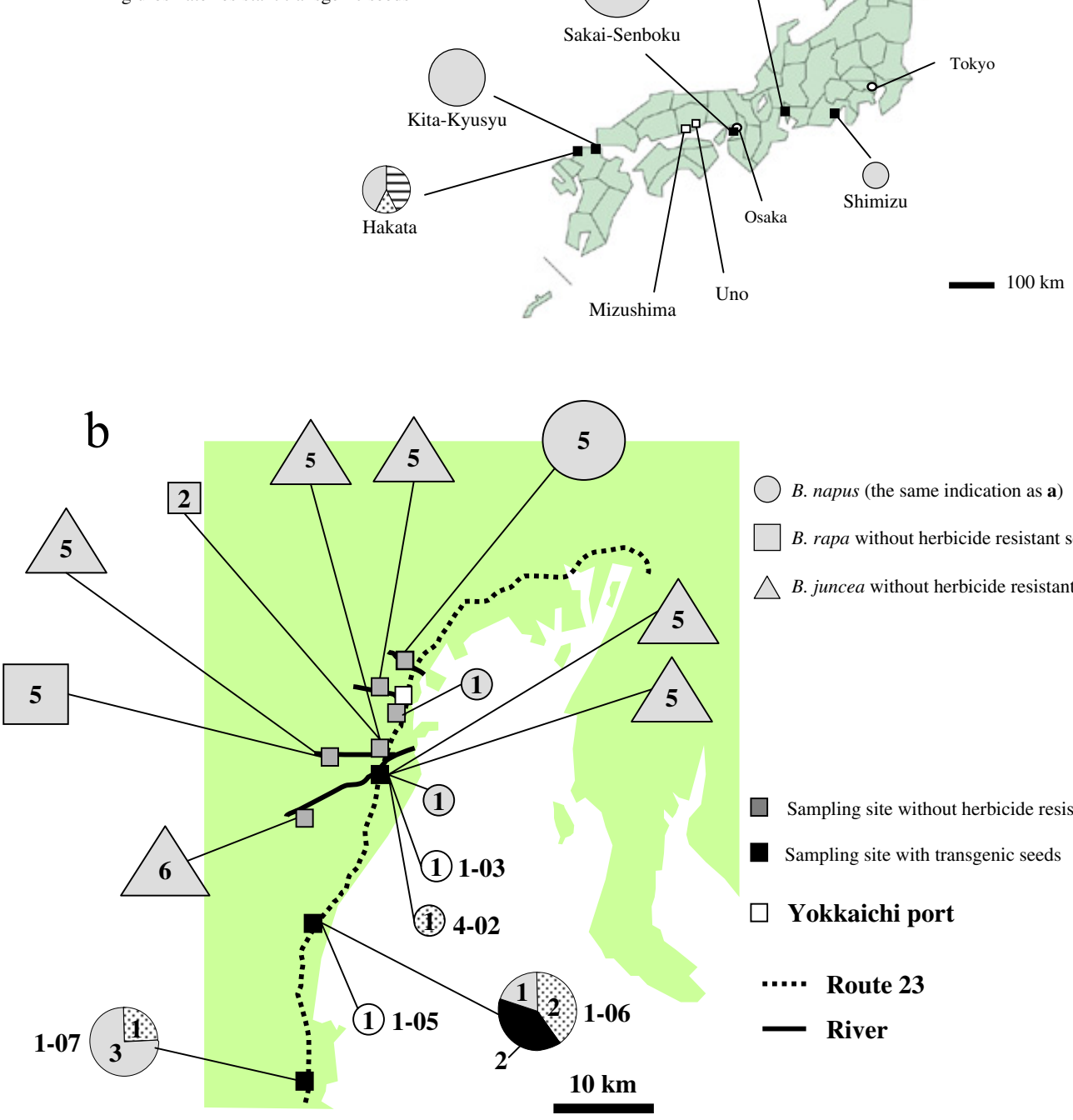

B. napus (the same indication as a)

B. rapa without herbicide resistant seeds

$\triangle$ B. juncea without herbicide resistant seeds

Sampling site without herbicide resistant seeds

Sampling site with transgenic seeds

$\square$ Yokkaichi port

Route 23

River

Figure 1. (a) Survey of the distribution of Brassica napus plants with herbicide-resistant seeds in major port areas in the west of Japan. Each port name represents an area including three types of sampling sites: ports, roadsides and riverbanks (see text). Open circle, representative city in Japan; closed box, port area with B. napus; open box, port area without B. napus (see Tab. 1). (b) Results in Yokkaichi port area. 1-03, 1-05, 1-06, 1-07 and 4-02, sampling site number (see Tab. 2). (a and b) The sizes of the circles, squares and triangles are proportional to the number of plants from which seeds of $B$. napus, B. rapa and B. juncea were collected in each area (a) or sampling site (b), respectively. Numbers of maternal plants from which seeds were collected are indicated for each sampling site (b). The sectors within the circles show the ratio of plants with and without herbicide resistance in each area (a) or sampling site (b). 
Transgenic multiple-herbicide-resistant oilseed rape in Japan

Table 1. Numbers of sampling sites, maternal plants and seedlings tested for detection of herbicide-resistance.

\begin{tabular}{|c|c|c|c|c|c|c|c|c|c|}
\hline \multirow{2}{*}{ Areas } & \multirow[t]{2}{*}{ Species } & \multicolumn{8}{|c|}{$\begin{array}{l}\text { Numbers of sampling sites, maternal plants } \\
\text { and derived seedlings treated with glyphosate or glufosinate }\end{array}$} \\
\hline & & Ports & & Roadsides & & Riverbank & & Total & \\
\hline \multirow{3}{*}{ Shimizu } & B. napus & 0 & (0) & 1 & $\begin{array}{r}(1) \\
17,18\end{array}$ & 0 & (0) & 1 & $\begin{array}{r}(1) \\
17,18\end{array}$ \\
\hline & B. rapa & 0 & (0) & 0 & (0) & 2 & $\begin{array}{r}(10) \\
129,89\end{array}$ & 2 & $\begin{array}{r}(10) \\
129,89\end{array}$ \\
\hline & B. juncea & 0 & (0) & 0 & (0) & 3 & $\begin{array}{r}(15) \\
236,198\end{array}$ & 3 & $\begin{array}{r}(15) \\
236,198\end{array}$ \\
\hline \multirow{3}{*}{ Yokkaichi } & B. napus & 1 & $\begin{array}{r}(1) \\
17,20\end{array}$ & $5^{2}$ & $\begin{array}{r}(12) \\
253,245\end{array}$ & $2^{2}$ & $\begin{array}{r}(6) \\
95,86\end{array}$ & 8 & $\begin{array}{r}(19) \\
365,351\end{array}$ \\
\hline & B. rapa & 0 & (0) & 0 & (0) & 2 & $\begin{array}{r}(7) \\
92,76\end{array}$ & 2 & $\begin{array}{r}(7) \\
92,76\end{array}$ \\
\hline & B. juncea & 0 & (0) & 0 & (0) & 6 & $\begin{array}{r}(31) \\
398,281\end{array}$ & 6 & $\begin{array}{r}(31) \\
398,281\end{array}$ \\
\hline \multirow{2}{*}{ Sakai-Senboku } & B. napus & 0 & (0) & 5 & $\begin{array}{r}(14) \\
245,237\end{array}$ & 0 & (0) & 5 & $\begin{array}{r}(14) \\
245,237\end{array}$ \\
\hline & B. juncea & 1 & $\begin{array}{r}(4) \\
66,68\end{array}$ & 0 & (0) & 5 & $\begin{array}{r}(28) \\
374,288\end{array}$ & 6 & $\begin{array}{r}(32) \\
440,356\end{array}$ \\
\hline \multirow{2}{*}{ Uno } & B. rapa & 0 & (0) & 0 & (0) & 3 & $\begin{array}{r}(15) \\
199,171\end{array}$ & 3 & $\begin{array}{r}(15) \\
199,171\end{array}$ \\
\hline & B. juncea & 1 & $\begin{array}{r}(5) \\
65,22\end{array}$ & 0 & (0) & 8 & $\begin{array}{r}(40) \\
262,63\end{array}$ & 9 & $\begin{array}{r}(45) \\
327,85\end{array}$ \\
\hline \multirow{2}{*}{ Mizushima } & B. rapa & 0 & (0) & 0 & (0) & 1 & $\begin{array}{r}(1) \\
14,10\end{array}$ & 1 & $\begin{array}{r}(1) \\
14,10\end{array}$ \\
\hline & B. juncea & 0 & (0) & 0 & (0) & 6 & $\begin{array}{r}(30) \\
441,349 \\
\end{array}$ & 6 & $\begin{array}{r}(30) \\
441,349\end{array}$ \\
\hline \multirow{3}{*}{ Kita-Kyusyu } & B. napus & 1 & $\begin{array}{r}(9) \\
170,171\end{array}$ & 0 & (0) & 0 & (0) & 1 & $\begin{array}{r}(9) \\
170,171\end{array}$ \\
\hline & B. rapa & 1 & $\begin{array}{r}(5) \\
75,73\end{array}$ & 0 & (0) & 5 & $\begin{array}{r}(29) \\
208,183\end{array}$ & 6 & $\begin{array}{r}(34) \\
283,256\end{array}$ \\
\hline & B. juncea & 5 & $\begin{array}{r}(25) \\
385,332\end{array}$ & 0 & (0) & 10 & $\begin{array}{r}(50) \\
679,609\end{array}$ & 15 & $\begin{array}{r}(75) \\
1064,941\end{array}$ \\
\hline \multirow{3}{*}{ Hakata } & B. napus & $5^{2}$ & $\begin{array}{r}(7) \\
120,120\end{array}$ & 0 & (0) & 0 & (0) & 5 & $\begin{array}{r}(7) \\
120,120\end{array}$ \\
\hline & B. rapa & 0 & (0) & 0 & (0) & 3 & $\begin{array}{r}(15) \\
120,136\end{array}$ & 3 & $\begin{array}{r}(15) \\
120,136\end{array}$ \\
\hline & B. juncea & 3 & $\begin{array}{r}(6) \\
0,0\end{array}$ & 0 & (0) & 10 & $\begin{array}{r}(49) \\
718,710\end{array}$ & 13 & $\begin{array}{r}(55) \\
718,710\end{array}$ \\
\hline \multirow{3}{*}{ Total } & B. napus & 7 & $\begin{array}{r}(17) \\
307,311\end{array}$ & 11 & $\begin{array}{r}(27) \\
515,500\end{array}$ & 2 & $\begin{array}{r}(6) \\
95,86\end{array}$ & 20 & $\begin{array}{r}(50) \\
917,897\end{array}$ \\
\hline & B. rapa & 1 & $\begin{array}{r}(5) \\
75,73\end{array}$ & 0 & (0) & 16 & $\begin{array}{r}(77) \\
762,665\end{array}$ & 17 & $\begin{array}{r}(82) \\
837,738\end{array}$ \\
\hline & B. juncea & 10 & $\begin{array}{r}(40) \\
516,422\end{array}$ & $\mathbf{0}$ & (0) & 48 & $\begin{array}{r}(243) \\
3108,2498\end{array}$ & 58 & $\begin{array}{r}(283) \\
3624,2920\end{array}$ \\
\hline
\end{tabular}

Numbers of maternal plants are in parentheses and numbers of herbicide-treated seedlings are in italic.

${ }^{1}$ Approximately 20 seeds were sown for each herbicide treatment per maternal plant.

${ }^{2}$ Herbicide-resistant seedlings were detected in some of these sampling sites. 
M. Aono et al.

Table 2. Numbers of herbicide-resistant seedlings from B. napus plants.

\begin{tabular}{|c|c|c|c|c|c|}
\hline Area-sampling site type & $\begin{array}{l}\text { Sampling } \\
\text { site no. }\end{array}$ & Plant no. & $\begin{array}{c}\text { Glyphosate-resistant } \\
\text { seedlings }\end{array}$ & $\begin{array}{l}\text { Glufosinate-resistant } \\
\text { seedlings }\end{array}$ & $\begin{array}{l}\text { Glyphosate- and glufosinate- } \\
\text { resistant seedlings }\end{array}$ \\
\hline \multirow{7}{*}{ Yokkaichi-roadside } & $1-03$ & $1-03-1$ & $20(20)$ & & \\
\hline & $1-05$ & $1-05-1$ & $14(20)$ & & \\
\hline & \multirow{4}{*}{$1-06^{4}$} & $1-06-1$ & $1\left(20^{1}\right)$ & $24^{3}(24)$ & $1\left(20^{1}\right)$ \\
\hline & & $1-06-2$ & & $14(14)$ & \\
\hline & & $1-06-3$ & $4\left(35^{2}\right)$ & $24\left(35^{2}\right)$ & $7\left(35^{2}\right)$ \\
\hline & & $1-06-4$ & & $18(18)$ & \\
\hline & $1-07$ & $1-07-1$ & & $19(19)$ & \\
\hline Yokkaichi-riverbank & $4-02$ & $4-02-1$ & & $20(20)$ & \\
\hline \multirow{4}{*}{ Hakata-port } & $1-15$ & $1-15-1$ & $15(20)$ & & \\
\hline & \multirow{3}{*}{$1-16^{4}$} & $1-16-1$ & $20(20)$ & & \\
\hline & & $1-16-2$ & & $17(19)$ & \\
\hline & & $1-16-3$ & $20(20)$ & & \\
\hline
\end{tabular}

Blank cells mean that no herbicide-resistant seedlings were detected. Numbers of seedlings germinated and used for detection of their herbicide resistance are shown in parentheses.

${ }_{1,2}$ The same number means the same seedling group.

${ }^{3}$ Two of 24 seedlings were immunochemically tested for glyphosate-resistance protein CP4 EPSPS, but the CP4 EPSPS was not detected. The other 22 seedlings were not tested for CP4 EPSPS, because they were already dead and removed when glyphosate-resistant seedlings were detected in the progeny of 1-06-1.

${ }^{4}$ At these sampling sites, the plants were approximately $70 \mathrm{~cm}$ apart.

Table 3. Primers and length of PCR products for detection of transgenes.

\begin{tabular}{llll}
\hline \multicolumn{1}{c}{ Transgenes } & \multicolumn{1}{c}{ Primers } & \multicolumn{1}{c}{ Sequences } & Length of PCR products (bp) \\
\hline \multirow{2}{*}{ cp4 epsps } & EPSPS7 & 5'-AAGAACTCCGTGTTAAGGAAAGCGA-3' & 320 \\
\cline { 2 - 4 } bar & EPSPS8 & 5'-AGCCTTAGTGTCGGAGAGTTCGAT-3' & \\
\hline \multirow{2}{*}{ barnase } & BAR7 & 5'-ACAAGCACGGTCAACTTCCGTAC-3' & 330 \\
\cline { 2 - 4 } & BAR8 & 5'-GAGCGCCTCGTGCATGCGCACG-3' & 174 \\
\cline { 2 - 4 } barstar & BARNASE4 & 5'-TCAGCCAGTCGCTTGAGTAA-3' & \\
\cline { 2 - 4 } & BARSTAR5 & 5'-AGTCATTAACGGGGAACAAATCAGA-3' & 316 \\
\hline
\end{tabular}

multiple-herbicide resistant seeds were detected, two types of herbicide resistant plants were growing adjacently (Tab. 2), suggesting that imported seeds including two types of transgenes spilled out at this site during transportation.

\section{Genotypes of detected transgenic plants and possibility of intraspecific pollen flow}

Since it is known that outcrossing rates between $12 \%$ and $47 \%$ can occur between adjacent oilseed rape plants 


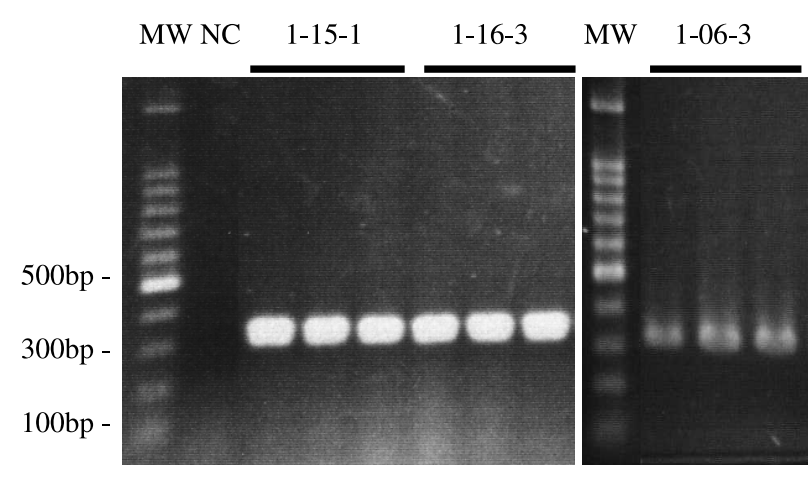

$\mathrm{c}$

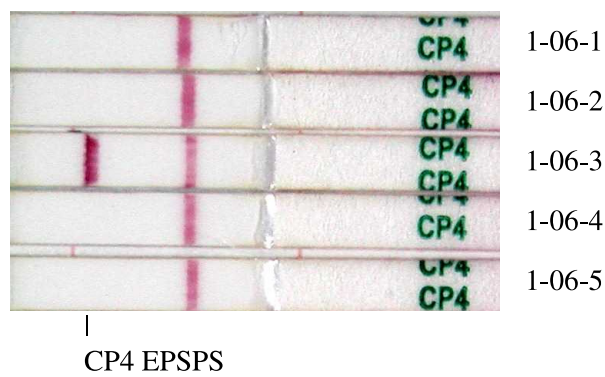

b

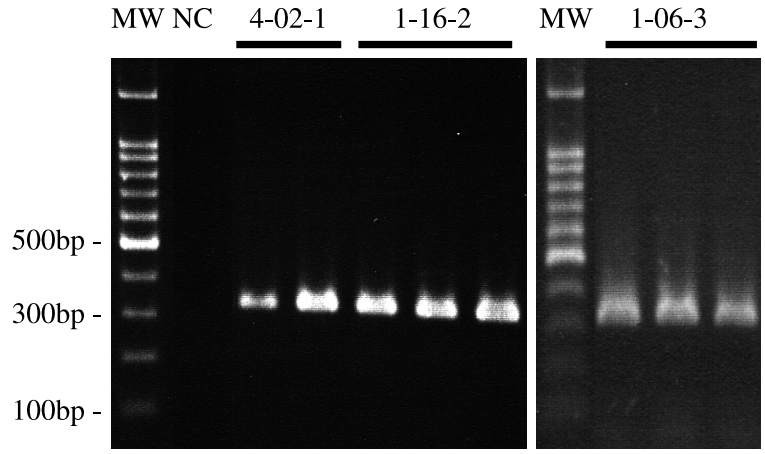

d

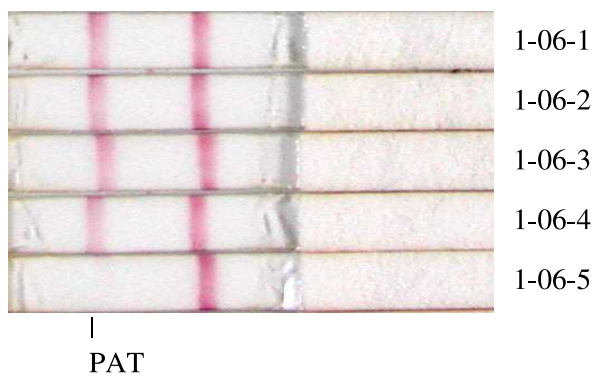

Figure 2. Representative results of the DNA and immunochemical analyses that confirmed the presence of transgenes in herbicide-resistant Brassica napus. (a and b) Results of PCR showing the presence of the cp4 epsps gene (a) or the bar gene (b) in leaves of herbicide-resistant seedlings: MW, molecular size marker; NC, herbicide-sensitive control plants; lanes 1-15-1 and 116-3 (a), glyphosate-resistant plants from Hakata Port; lanes 4-02-1 and 1-16-2 (b), glufosinate-resistant plants from Yokkaichiriverbank and Hakata Port, respectively; lanes 1-06-3 (a and b), glyphosate- and glufosinate-resistant plants from Yokkaichiroadside. (c and d) Results of immunochemical chromatography, showing the presence of CP4 EPSPS (c) or PAT (d) in seeds collected from B. napus plants growing at a Yokkaichi-roadside: lanes 1-06-1, 1-06-2 and 1-06-4, portions of the seeds from which glyphosate-sensitive and glufosinate-resistant seedlings were grown; lane 1-06-3, a portion of the seeds from which glyphosateresistant and glufosinate-resistant seedlings were grown; lane 1-06-5, a portion of the seeds from which glyphosate-sensitive and glufosinate-sensitive seedlings were grown. Lane numbers are identical to plant no. (see Tab. 2).

(Becker et al., 1992) despite a high level of self-fertility (Williams et al., 1986), the collected B. napus seeds are likely to have been produced by both self-pollination and cross-pollination. Assuming that the collected B. napus seeds were produced by self-pollination or by crosspollination with wild type pollen, the herbicide-resistant phenotypes of all the progeny of 1-03-1, 1-06-2, 1-06-4, $1-07-1,4-02-1,1-16-1$ and 1-16-3 indicate that those transgenic seeds were produced on transgenic maternal plants that were homozygous for each transgene (Tab. 2). On the other hand, segregation ratios to herbicide resistant/sensitive in the seedlings derived from 1-05-1, 115-1 and 1-16-2 indicate that the maternal plants were hemizygous for each transgene (Tab. 2). However, the possibility that the transgenic seeds were formed on nontransgenic maternal plants by crossing with transgenic pollen cannot be entirely excluded.

Using the remaining seeds from plants 1-06-1 and 106-3, which had borne both glyphosate-resistant and glufosinate-resistant seeds, segregation ratios of progeny of these two plants were investigated for the presence or absence of the herbicide-resistance proteins (Tab. 4). The coexistence of two kinds of the herbicide-resistance proteins in a single seed suggests that maternal plants were not susceptible, but they had at least one of the transgenes, although the possibility that both of transgenes were derived from a single pollen grain with multiple-herbicide tolerance cannot entirely be excluded. Since not all the 
Table 4. Segregation of detectable CP4 EPSPS or PAT in progeny of B. napus plants growing on the Yokkaichi roadside.

\begin{tabular}{cccccc}
\hline \hline Plant no. & CP4 EPSPS & PAT & CP4 EPSPS and PAT & Neither protein & Total \\
\hline $1-06-1$ & $1(0)$ & $99^{1}(97)$ & $4(3)$ & $0(0)$ & $\mathbf{1 0 4}$ \\
\hline $1-06-3$ & $6(2)$ & $31(7)$ & $9(2)$ & $1(1)$ & $\mathbf{4 7}$ \\
\hline
\end{tabular}

Results were obtained using seedlings from seeds in addition to those in Table 2. Numbers of tested seeds are in parentheses, included in total.

${ }^{1}$ The number includes two glufosinate-resistant seedlings which were confirmed not having glyphosate-resistance protein CP4 EPSPS, but does not include the remaining 22 glufosinate-resistant seedlings which were not tested for the CP4 EPSPS (see Tab. $2^{3}$ ).

seeds were resistant to either of the herbicides, neither transgene could have been homozygous in these maternal plants. Additionally, it is possible that the glyphosate resistance of the seeds did not come from their maternal plant but from pollen of other plants, because glyphosate resistant/sensitive ratios were 5:99 and 15:32 for 1-06-1 and 1-06-3, respectively (Tab. 4), and evidently smaller than 1:1, which is the expected ratio in a maternal plant with hemizygous cp4 epsps. The plant with glyphosateresistant seeds, 1-05-1, could be a possible glyphosateresistant pollen source because the distance between 1-05 and 1-06 was ca. $300 \mathrm{~m}$, and pollen can be dispersed over this distance by wind or insects (OGTR, 2002; Warwick et al., 2004). There is also the possibility of crosspollination of these maternal plants with pollen having bar from other plants. For 1-06-1, glufosinate resistant/ sensitive ratio was 103:1 (Tab. 4) and markedly larger than $3: 1$ which is expected if all the seeds were obtained by selfpollination of a maternal plant with hemizygous bar, although glufosinate resistant/sensitive ratio for 1-06-3 was 40:7 which is not significantly different from 3:1. Actually, 1-06-1 and 1-06-3 were growing adjacently, and could mutually be a glufosinate-resistant pollen source. Other glufosinate-resistant plants, 1-06-2 and 1-06-4, detected in the same sampling site could also be glufosinate-resistant pollen sources (Tab. 2). Since a community at the sampling site 1-06 consisted of approximately $20 \mathrm{~B}$. napus plants, there may possibly be other pollen sources that were not collected during this investigation. However, only one glufosinate-sensitive progeny seedling was detected in over a hundred seeds from 1-06-1 (Tab. 4), suggesting that seed cross contamination can not be ruled out. Thus 1-06-1 could have been homozygous for bar.

Moreover, existence of other transgenes, barnase (a ribonuclease that confers male sterility in plants, Mariani et al., 1990) and barstar (a barnase inhibitor that restores fertility to male sterile plants, Mariani et al., 1992), introduced into B. napus accompanied with bar, was also investigated in progeny of 1-06-3 by PCR using specific primers (Tabs. 3 and 5). The PCR products of expected
Table 5. Presence of four transgenes in progeny of $B$. napus plant, 1-06-3, growing on the Yokkaichi roadside.

\begin{tabular}{ccccc}
\hline cp4 epsps & bar & barnase & barstar & Number of seedlings \\
\hline+ & + & + & + & 3 \\
\hline+ & + & + & - & 2 \\
\hline+ & + & - & + & 2 \\
\hline+ & + & - & - & 0 \\
\hline+ & - & + & + & 0 \\
\hline+ & - & + & - & 0 \\
\hline+ & - & - & + & 0 \\
\hline+ & - & - & - & 4 \\
\hline- & + & + & + & 10 \\
\hline- & + & + & - & 0 \\
\hline- & + & - & + & 14 \\
\hline- & + & - & - & 0 \\
\hline Total & & & & $35^{1}$
\end{tabular}

${ }^{1}$ The same seedling group as shown in Table $2^{2}$. There were no wild-type genotype seedlings.

length were detected for these two transgenes (data not shown) and their nucleotide sequences were identical to a part of DNA sequences registered in INSD as barnase (accession no. E31988) or as barstar (accession no. A21284). The varied genotypes of these additional transgenes observed in the progeny of 1-06-3 also suggest that at least one pollination event occurred between two herbicide resistant varieties of transgenic plants, although the numbers of seedlings were too small to reach a statistically significant conclusion. These results also demonstrated that the glufosinate-resistant B. napus seed pool imported into Japan had both barstar and barnase. However, since barnase/barstar hybrid lines approved to be cultivated in Canada (Agbios GM database, http:// www.agbios.com/dbase.php) can produce multiple genotypes of seeds, those imported seeds that might potentially escape and become parental plants seem to have not a single genotype with barnase and barstar but multiple genotypes. Namely, all imported seeds may not have hemizygous barnase and hemizygous barstar, for 
example, but they may consist of multiple genotypes, such as homozygous barnase and no barstar, hemizygous barnase and homozygous barstar, and so on. Hence, the genotype of the parental plants can hardly be determined by segregation pattern of these two genes in progeny.

Thus, intraspecific gene flow as a result of pollen flow is likely to have occurred between transgenic maternal plants and other transgenic plants. Although Simard et al. (2005) have reported that glyphosate- and glufosinateresistant B. napus plants had similar fitness to singleherbicide-resistant plants, persistence of the multipleherbicide-resistant plants should be investigated in the future around the sampling sites where they were detected, in order to monitor herbicide-resistant gene flow in the feral populations of oilseed rape plants. Since the genotype of the maternal plants 1-06-1 and 1-06-3, was not investigated directly, it is not clear whether multipleherbicide-resistance in the progeny of these plants was brought about by a single cross-pollination in this generation in Japan, or whether multiple-herbicideresistant hybrid seeds had been produced in Canada. Collection of tissue parts of maternal plants, such as seedpods or stems, will be indispensable to future investigations.

Two transgenic oilseed rape varieties investigated in this study have been approved to be imported into Japan since 1996 and transgenic B. napus plants with glyphosate-resistance or glufosinate-resistance transgenes were first detected in Japan in 2003 (Saji et al., 2005). Therefore, regardless of the probability of crossing between two transgenic varieties, the time since the first detection of feral transgenic B. napus plants in Japan is too short for discussion of the formation of self-sustaining populations.

\section{Interspecific flow of transgenes}

The plants with transgenic seeds were limited to B. napus, which is the only imported transgenic species in this genus; no transgenic offspring were detected in any seeds collected from B. rapa or B. juncea (Tab. 1 and Fig. 1), as in the previous investigation (Saji et al., 2005). Thus, transgene introgression into these species has not yet been found, even at the Yokkaichi riverbank sampling site where a community of $B$. juncea plants was located ca. $80 \mathrm{~m}$ from $B$. napus plant 1-03-1 with glyphosate-resistant seeds (Fig. 1b). However, introgression of transgenes at such sampling sites as riverbanks under bridges on the transportation routes should be investigated further, since riverbanks are a major habitat of feral Brassica species in Japan. In the present investigation, the occurrence of interspecific cross-pollination resulting in transgenic seeds at a very small portion of the collected seeds of $B$. rapa or $B$. juncea, may have been overlooked, since not all the collected seeds were tested for the existence of the transgenes and/or herbicide resistance. Nevertheless, checking a small number of seeds out of a seed pool of a maternal plant appears to be efficient enough to determine the presence of the transgene(s) in a maternal plant. While it has been reported that outcrossing between B. napus and these two related species can occur under natural conditions, reduced fitness of hybrid progeny was described (Bing et al., 1996; reviewed in OGTR, 2002). Thus, it may be more important to detect the presence of transgenic-hybrid maternal plants producing transgenic offspring than to find cross-pollination events themselves, i.e. $\mathrm{F}_{1}$ transgenic seeds present at very low levels in a large seed pool from wild-type maternal plants.

\section{CONCLUSION}

This is the first report that suggests the occurrence of outcrossing between crop plants with different transgenes in feral Brassica populations in Japan, a country where the corresponding transgenic crop plants have not been commercially cultivated, although the detection of transgenic oilseed rape, including multiple-herbicidetolerant volunteers, outside cultivation has already been reported in Canada (Hall et al., 2000; Warwick et al., 2004). The presence of multiple-herbicide resistant seeds implies a probability of pollen-mediated intraspecific gene flow in natural conditions. There also seems to be an opportunity of seed-mediated gene flow from imported transgenic oilseed rape to current feral populations of Brassica species in Japan. Our investigation is proceeding to monitor establishment or propagation of feral transgenic oilseed rape plants as well as intraspecific and interspecific flow of the transgenes at sampling sites where transgenic seeds were detected in the present investigation. The results obtained in the present study, together with the results of our previous study (Saji et al., 2005), suggest that feral transgenic oilseed rape plants are growing in some areas in Japan.

\section{MATERIALS AND METHODS}

\section{Sampling and analyses of herbicide resistance}

We collected seeds from May to July 2005 from a plant each of B. napus, B. rapa, and B. juncea found growing at each sampling site. The average seed number per plant was approximately $1300 \pm 870$ SD calibrated by the weight of 10 seeds. Since these species are highly outcrossing, 
insect-pollinated plants, sampling from a maternal plant allows sampling of many paternal plants. The seeds were collected from a total of 95 sampling sites in seven areas west of Tokyo (Shimizu, Yokkaichi, Sakai-Senboku, Uno, Mizushima, Kita-Kyusyu and Hakata) where major ports exist. A portion of the seeds (approximately 20 per plant) from each maternal plant was sown in a plastic case set in a glasshouse and a total of 917 B. napus, 837 B. rapa and 3624 B. juncea seedlings were treated twice (at 3 weeks and at 4 weeks after sowing, the four- to five-leaf stage) with $33.4 \mathrm{~kg}$ ae.ha ${ }^{-1}$ glyphosate (Roundup Highload, Monsanto, St. Louis, MO, USA). Another portion of the seeds of similar numbers, also from each maternal plant, was similarly grown and a total of 897 B. napus, 738 B. rapa and 2920 B. juncea seedlings were treated twice (at 4 weeks and at 31 days after sowing) with $7.5 \mathrm{~kg}$ ai.ha ${ }^{-1}$ glufosinate (Basta, Hoechst Schering AgrEvo, Frankfurt, Germany). Seedlings that survived these herbicide treatments were analyzed as described below to detect the presence of transgenes. Another portion of the collected seeds ( 5 per plant) from each maternal plant was used in immunochemical chromatography (see below) to test for the presence of the products of the glyphosate-resistance and/or glufosinate-resistance transgenes. A B. napus maternal plant, 1-06-3, was presumed to have multiple-herbicide resistant progeny by previously performed immunochemical analysis of seeds. Thus 35 seedlings derived from 1-06-3 were first analyzed immunochemically then the expected resistance to appropriate herbicide(s) of each seedling was confirmed. Four or 24 seedlings were treated with glyphosate or glufosinate, respectively, and 7 seedlings were successively treated with glyphosate and glufosinate. Only glufosinate resistance but not glyphosate resistance was detected in the previous immunochemical analyses of a portion of seeds from another $B$. napus maternal plant, 1-06-1. Of 20 seedlings treated with glyphosate, however, two seedlings unexpectedly survived, and these two seedlings were then treated with glufosinate.

\section{Immunochemical analyses}

For immunochemical chromatography, crude extracts of leaf tissue or seeds were analyzed to detect the enzyme that confers resistance to glyphosate (CP4 EPSPS), and/or the enzyme that confers resistance to glufosinate (PAT), using the TraitChek LL Test Kit (Strategic Diagnostic Inc., Newark, DE, USA) and the Reveal kit (Neogen, Lansing, MI, USA), respectively, as described (Saji et al., 2005).

\section{DNA analyses}

DNA was extracted from another leaf of the herbicideresistant plant using Nucleon PhytoPure, a plant DNA extraction kit (Amersham International plc, Buckinghamshire, UK) and analyzed by means of PCR, using the sets of primers for cp4 epsps, bar, barnase and barstar genes (Tab. 3). Amplifications using ca. $100 \mathrm{ng}$ of extracted DNA were carried out in $20 \mu \mathrm{l}$ reaction mixtures containing $1 \mathrm{X}$ PCR buffer (Takara Bio Inc., Shiga, Japan), $0.2 \mathrm{mM}$ of each dNTP, $1 \mu \mathrm{M}$ of each primer and $2.5 \mathrm{U}$ of Ex-Taq polymerase (Takara Bio Inc., Shiga, Japan), with denaturation at $94{ }^{\circ} \mathrm{C}$ for $3 \mathrm{~min}, 35$ cycles of denaturation at $94{ }^{\circ} \mathrm{C}$ for $1 \mathrm{~min}$, annealing for $2 \mathrm{~min}$ at $55^{\circ} \mathrm{C} / 60{ }^{\circ} \mathrm{C}$ for barnase/the other three genes, respectively, elongation at $72{ }^{\circ} \mathrm{C}$ for $3 \mathrm{~min}$, and final elongation at $72^{\circ} \mathrm{C}$ for $10 \mathrm{~min}$. The PCR-amplified products were then subjected to electrophoresis on $4 \%$-agarose gel. The DNA bands of appropriate sizes were recovered from the gel and their nucleotide sequences were determined using a DNA sequencer (PRISM-3100 or PRISM-3700, Applied Biosystems, Foster City, CA, USA) to confirm that these products corresponded to fragments of the respective genes.

\section{ACKNOWLEDGMENTS}

We thank Naoto Yasuda and Ryoko Sakuramata of the Ministry of the Environment of Japan for valuable discussions and critical reading of the manuscript. We also thank Kanako Azami for her technical assistance. This project was funded by the Ministry of the Environment of Japan.

Received April 19, 2006; accepted September 5, 2006.

\section{REFERENCES}

Barry GF, Kishore GM (October 31, 1995) Glyphosate tolerant plants. United States, Patent No. 5463175

Barry GF, Kishore GM, Padgette SR, Taylor ML, Kolacz KH, Weldon M, Re DB, Eichholtz DA, Fincher K, Hallas L (1992) Inhibitors of amino acid biosynthesis: Strategies for imparting glyphosate tolerance to crop plants. In Singh BK, Flores HE, Shannon JC, eds, Biosynthesis and Molecular Regulation of Amino Acids in Plants, American Society Plant Physiologists, Rockville, MD, USA, pp 139-145

Becker HC, Damgaard C, Karlsson B (1992) Environmental variation for outcrossing rate in rapeseed (Brassica napus). Theor. Appl. Genet. 84: 303-306 
Beckie HJ, Warwick SI, Nair H, Séguin-Swartz G (2003) Gene flow in commercial fields of herbicide-resistant canola (Brassica napus). Ecol. Appl. 13: 1276-1294

Bing DJ, Downey RK, Rakow GFW (1996) Hybridizations among Brassica napus, B. rapa and B. juncea and their two weedy relatives $B$. nigra and Sinapis arvensis under open pollination conditions in the field. Plant Breed. 115: 470-473

Comai L, Facciotti D, Hiatt WR, Thompson G, Rose RE, Stalker DM (1985) Expression in plants of a mutant aroA gene from Salmonella typhimurium confers tolerance to glyphosate. Nature 317: 741-744

Crawley MJ, Brown SL, Hails RS, Kohn DD, Rees M (2001) Transgenic crops in natural habitats. Nature 409: 682-683

EFSA (the European Food Safety Authority) (2004) Guidance document of the scientific panel on genetically modified organisms for the risk assessment of genetically modified plants and derived food and feed. http://www.efsa.eu.int/ science/gmo/gmo_guidance/660_en.html

Friesen LF, Nelson AG, Van Acker RC (2003) Evidence of contamination of pedigreed canola (Brassica napus) seedlots in western Canada with genetically engineered herbicide resistance traits. Agron. J. 95: 1342-1347

Hall L, Topinka K, Huffman J, Davis L, Good A (2000) Pollen flow between herbicide-resistant Brassica napus is the cause of multiple-resistant B. napus volunteers. Weed Sci. 48: 688-694

ISAAA (International Service for the Acquisition of Agribiotech Applications) (2006) ISAAA Briefs 34-2005: Global Status of Commercialized Biotech/GM Crops: 2005. http:// www.isaaa.org/

Jørgensen RB, Andersen B, Landbo L, Mikkelsen TR (1996) Spontaneous hybridization between oilseed rape (Brassica napus) and weedy relatives. Acta Horticul. 407: 193-197

Mariani C, De Beuckeleer M, Truettner J, Leemans J, Goldberg RB (1990) Induction of male sterility in plants by a chimaeric ribonuclease gene. Nature 347: 737-741

Mariani C, Gossele V, De Beuckeleer M, De Block M, Goldberg RB, De Greef W, Leemans J (1992) A chimaeric ribonuclease-inhibitor gene restores fertility to male sterile plants. Nature 357: 384-387

OECD (Organisation for Economic Cooperation and Development) (1997) Series on harmonization of regulatory oversight in biotechnology No.7; Consensus document on the biology of Brassica napus L. (oilseed rape). http:// www.olis.oecd.org/olis/1997doc.nsf/LinkTo/ocde-gd(97)63

OGTR (Office of the Gene Technology Regulator) (2002) The biology and ecology of canola (Brassica napus). http:// www.ogtr.gov.au/pdf/ir/brassica.pdf

Padgette SR, Kolacz KH, Delannay X, Re DB, Lavallee BJ, Tinius CN, Rhodes WK, Otero YI, Barry GF, Eichholtz DA, Peschke VM, Nida DL, Taylor NB, Kishore GM (1995) Development, identification, and characterization of a glyphosate-tolerant soybean line. Crop Sci., 35: 1451-1461

Saji H, Nakajima N, Aono M, Tamaoki M, Kubo A, Wakiyama S, Hatase Y, Nagatsu M (2005) Monitoring the escape of transgenic oilseed rape around Japanese ports and roadsides. Environ. Biosafety Res. 4: 217-222

Simard MJ, Légère A, Séguin-Swartz G, Nair H, Warwick S (2005) Fitness of double vs. single herbicideresistant canola source. Weed Sci. 53: 489-498

Stalker DM, McBride KE, Malyj LD (1988) Herbicide resistance in transgenic plants expressing a bacterial detoxification gene. Science 242: 419-423

Thompson CJ, Movva NR, Tizard R, Crameri R, Davies JE, Lauwereys M, Botterman J (1987) Characterization of the herbicide-resistance gene bar from Streptomyces hygroscopicus. EMBO J. 6: 2519-2523

USDA (United States Department of Agriculture) (2005a) USDA Foreign Agricultural Service, Global Agriculture Information Network Report, Australia Biotechnology Agricultural Biotechnology Annual Report 2005, GAIN Report Number AS5024. http://www.fas.usda.gov/gainfiles/ 200507/146130258.doc

USDA (United States Department of Agriculture) (2005b) USDA Foreign Agricultural Service, Global Agriculture Information Network Report, Canada Biotechnology Agricultural Biotechnology Report 2005, GAIN Report Number CA5044. http://www.fas.usda.gov/gainfiles/200507/ 146130196.doc

Warwick S, Beckie HJ, Simard MJ, Légère A, Nair H, Séguin-Swartz G (2004) Environmental and agronomic consequences of herbicide-resistant (HR) canola in Canada. In Den Nijs HCM, Bartsch D, Sweet J, eds, Introgression from Genetically Modified Plants into Wild Relatives, CABI publishing, Wallingford, Oxfordshire, UK, pp 323-337

Williams IH, Martin AP, White RP (1986) The pollination requirements of oil-seed rape (Brassica napus L.). J. Agric. Sci. 106: 27-30 